DOI : https://10.24260/khatulistiwa.v10i1.1608

\title{
DESIGNING MEETING POINT SYI'AH-SUNNI IN INDONESIA
}

\author{
Ade Jamaruddin \\ UIN Suska Riau,Indonesia ade.jamarudin@uin-suska.ac.id \\ Asmal May \\ UIN Suska Riau, Indonesia
}

\section{HIGHLIGHT}

- The difference between the understanding of Shi'a and Sunni, according to him, the trigger of conflict and mutual infidelity is to forgive, cannot be united until the end. If the Sunni forgives Syi'ah, clearly the opposite will happen, one way that must be taken is mutual tolerance.

\section{ARTICLE HISTORY}

$\begin{array}{lll}\text { Submit } & : & \text { Dec 19, } 2019 \\ \text { Revision } & : & 3 \mathrm{Feb} 2020 \\ \text { Revision } & : & 15 \mathrm{Feb} 2020 \\ \text { Minor } & & \\ \begin{array}{l}\text { Accepted } \\ \text { Published }\end{array} & : & \text { Mar 27, } 2020 \\ \end{array}$

\section{ABSTRACT}

Movement of thought always influences the human condition both positive and negative influences. The emergence of a belief stream begins with a movement that seeks to reconstruct, purify, innovate against conventional and normative teachings in a religion. One of the schools of Islam is Syi'ah. This research is library research, which is descriptive, analytical and comparative. The data analysis used is deductive and descriptive normative. The factor of the differences in Syi'ah's character in Indonesia is not because of the Indonesian culture. However, Syiah level of understanding of the doctrine of the Imamate gave birth to a different typology. The Indonesian cultural factors only color the skin, not to change the view of faith. The difference between the understanding of Shi'a and Sunni, according to him, the trigger of conflict and mutual infidelity is to forgive, cannot be united until the end. If the Sunni forgives Syi'ah, clearly the opposite will happen, one way that must be taken is mutual tolerance. The rationale for the Shiites is to practice it because of the reason they hold to a strong proposition. The view of the Syi'ah towards his understanding is the same as that of the Sunnah expert on his understanding.

\section{Keyword : $\quad$ Designing, Meeting Point, Sunni Syi'ah, Indonesia}

Copyright@2020 The Authors. Published by The Institute for Research and Community Service Pontianak State Institute for Islamic Studies This is an Open Access article under of CC BY-NC-ND 4.0 License https://creativecommons.org/licenses/by-nc-nd/4.0
KHATULISTIWA: Journal of Islamic Studies Vol. 10, No. 1. March 2020
DOI: https://10.24260/khatulistiwa.v10i1.1608 Designing Meeting Point Syi'ah-Sunni in Indonesia 


\section{A. INTRODUCTION}

In the history of the development of the flow in Islam, Indonesia has been an eyewitness to this reality for several periods of time. The emergence of all kinds of sects and the flow of "mysticism" is also not something that is unique to developing countries. Indeed, in a highly developed country, such as the United States, this phenomenon is very prominent. Presumably, it is not only the emergence of the schools themselves that are the problem, but the types of schools that attract many new followers.

The period 1880 to 1915, for example, was the heyday of the tarekat in Indonesia; the influence and number of followers grew rapidly. Other movements or religious groups were not very prominent at that time. Congregations have become a forum for small people's rebellion against colonialists and indigenous civil service, not because there is a revolutionary character in the tarekat itself, but because of the number and social background of the adherents, because of their organizational structure (verticalhierarchical), and because of the "thaumaturgical" aspect it (immunity, supernatural powers).

The existence of new streams that emerge at this time is a part of other streams that are a challenge from the previous ones too, from time to time and continue to always be there. Until now, the above phenomenon cannot be avoided. Freedom of religion is an open choice for the community that leads to the progress of democracy.

However, the problem is that the more open the faucet of tolerance, the more rapidly the emergence of new flows in Islam, and the more blurred the real Islam. Because all these schools strongly believe that Islam is the most correct. Conversely, the more closed the tolerance faucet, the more opportunities for the expression "takfiri" as the cause of conflict.

In initiating this paper, the emergence of new schools is a manifestation of the current flow of human thought, which develops naturally. This movement of thought always influences the human condition both positive and negative influences. The emergence of a belief stream begins with movements that want to try to reconstruct, purify, innovate, and so on conventional and normative teachings in a particular religion or belief.

But sometimes, according to the expectations of some people, the efforts that they do often create noise, because they are deemed deviating from their original Islam, so that the growing flow eventually creates a teaching and even raises as if new Islam.One of the schools in Islam is those who call themselves Syi'ah or Syi'iy (the person). One of the cases of Syi'ah which had been "horrendous" was the emergence of cases of riots in Sampang Madura, which were driven by family conflicts. But in its development, these conflicts overlapped with 
political issues, as well as misunderstandings with the accusation of "infidels" regarding beliefs in their religious practices. This paper tries to analyze where the root of the problem is the cause of the emergence of conflict, while providing some notes on the fundamental differences between the two groups, and it is hoped that it can provide learning for all Islamic societies in the archipelago.

\section{B. METHOD}

This research is library research, and is descriptive, analytical and comparative. The data sources used in this study are sourced from primary and secondary data. In collecting data using library books, journals, magazines, articles, interviews (interviews) and documentation methods. Data analysis used in this study is deductive with a normative descriptive approach. In its operations, this research emphasizes more on the review and study of designing Sunni Syi'ah meeting points in Indonesia as well as the literature that has to do with this research. (Suyuti Ali, 2000: 46)

\section{Data analysis technique}

According to Marzuki, the purpose of data analysis in this study is to narrow and limit the findings so that they become a regular, structured and more meaningful data. (Marzuki, 1989: 87) An analyst is an attempt to find answers to questions from a formulated formula. In qualitative research, Lexy J Moleong explained that the steps that must be taken in data analysis are unit processing (unityzing), categorization and interpretation of data. (Lexy J Moleong, 2005: 189).

The brief description of the steps taken to analyze the data in this study are as follows:

a. Unitization of data, namely data grouped based on the framework of thought.

b. Data categorization is arranged according to the problem formulation and research objectives.

c. Data interpretation is based on theory which is then interpreted.

In the process, researchers use deductive and inductive analysis. The deductive method is used in order to obtain an overview of Designing the Sunni Syi'ah Meeting point in Indonesia. While the inductive method, is used in order to obtain a picture of the dialectical process between the realities faced by Religion in Indonesia. 


\section{RESULT AND DISCUSSION}

\section{Source of Conflict in Islam}

Many streams appear in various regions with their respective phenomena. As Ma'ruf Amin said, based on the findings of the MUI, various streams in Islam grew and developed, in almost all parts of Indonesia. They identify as Muslim groups. But said people, the teachings they practice are contrary to Islamic law (heresy).

A stream is called heretical if, what is taught has deviated from the standard rules of religious teachings. Some say that if in Islam it has deviated from the arulul of faith and the arkanul of Islam. But, according to the Chairperson of the MUI Fatwa Council, Ma'ruf Amin, the deviant notion "is outside the agreement of the area of difference and deviates beyond the authentic manhaj". Like: when someone claims to be a reformer of Islam and he says the five daily prayers are not compulsory, or may not be done in Arabic, then he can be called heretical. Likewise when there are people who claim to be Islam but believe there is a prophet after the Prophet Muhammad. then this is also called a cult. And other teachings that have deviated from the standard rules of Islam (Qat'i).

The philosophers were also condemned by some Islamic philosophers. Imam Ghazali for example, forgives the teachings of two great Islamic philosophers, Al-Farabi and Ibn Sina on three theological issues. However, Imam Ghazali never asked them to establish their own religion which was separate from Islam and this also took place in Indonesia, seen in the history of schools which were considered heretical to appear in Indonesia from time to time.

Basically, the source of the emergence of socio-religious conflict lies in every person who embraces the flow in understanding the flow he adheres to. They tend to prioritize single truth (truth claim), the most correct flow. They feel that the arrival of the stream is the bearer of truth, and certainly will threaten the existence of the existing stream first, and the point lies in the difference in interpretation. (Nils Bubant, 2004: 19)

Actually there is no need to confront violence to solve problems that from history have always been a matter of religious people, maybe some of the things below can be one of input for us to solve the existing problem: by developing polite dialogue (wajadilhum bil lati hisan ahsan). Islamic teachings emphasize the safety of various parties. Peaceful ways to overcome various acts of violence need to be done, a wise form of rejection, with discussion and debate well. The level of maturity of the Muslim community is not fully visible, if there are still many who take emotional actions by destroying public places. (Nils Bubant, 2004: 19) 


\section{History of the emergence of Syi'ah}

Regarding the emergence of Syi'ah in history there are differences among experts. According to Abu Zahrah, the Shi'ites began to emerge during the late reign of Usman bin Affan and then grew and developed during the reign of Ali bin Abi Talib, while according to Watt, the Shi'ites only really emerged when the war between Ali and Mu'awiyah took place known as the Shiffin war. In this war, in response to Ali's acceptance of arbitration offered by Mu'awiyah. Ali's troops were told to split into two. One group supported Ali's (Syi'ah's) attitude and the second group opposed Ali's attitude (Khawarij). (Abu Zahrah, 1996: 34).

The syi'ah themselves argue that the appearance of Syi'ah is related with the problem of the successor (Caliph) of the Prophet SAW. They rejected the Caliphate of Abu Bakr, Umar bin Khathtab, and Usman bin Affan because in their view only Ali bin Abi Talib had the right to replace the Prophet SAW. Ali's leadership in the view of Syi'ah is in line with the signs given by the Prophet, in his lifetime, as historical evidence, including:

1. At the beginning of prophethood when Muhammad SAW was ordered to deliver da'wah to his relatives, the first to accept was Ali bin Abi Talib. It is said that the Prophet at that time said that the person who first met his invitation would be his successor and heir. In addition, throughout Muhammad's prophethood, Ali was an extraordinary person. (Abdur Razak, Rosihan Anwar, 2006: 90 )

2. The main evidence of Ali's legitimate successor to the Prophet was the Ghadir Khumm event. It is said that when returning from the last Hajj, on the way from Mecca to Medina in a desert called Ghadir Khumm. The Prophet chose Ali as his successor before the masses who accompanied him. In that event, the Prophet not only appointed Ali as the general leader of the people (waliyatul 'ammali), but also made Ali as the Prophet himself, as their protector (guardian). but the reality speaks differently. (Abdur Razak, Rosihan Anwar, 2006: 38 )

3. Contrary to their expectations, when the Prophet died and his body was not buried, another group went to the mosque to determine the new leader because of the sudden loss of the leader, while members of the Prophet's family and some friends were still busy preparing for the Prophet's funeral . This group which later became the majority acted further and very hastily chose new leaders on the grounds of people's welfare and solving their problems at that time. They did it without negotiating first with ahlul bait, relatives, or friends who were still taking care of the funeral. They don't tell the least. Thus, Ali's friends are faced with an unusual thing that has changed again (faith accomply). (Abdur Razak, Rosihan Anwar, 2006: 39-40 ) 
4. Because of this fact an attitude emerged from the Muslims who opposed the Caliphate and the majority in certain matters of belief. They still maintain that the substitute for the prophet and the legitimate religious ruler is Ali. They believe that all spiritual and religious issues must refer to him and invite the public to follow him (Abdur Razak, Rosihan Anwar, 2006: 91 )

This is what is called the Syi'ah people. But more than that, as Nasr said, the main reason for the emergence of Shi'a lies in the fact that this possibility exists in the revelation of Islam itself, so it must be realized. ((Abdur Razak, Rosihan Anwar, 2006: 91 )

Differences of opinion among experts regarding the Syi'ah circles are natural. Historically, Shia Islam in Indonesia has existed since Islam entered Indonesia for the first time. This fact has been referred to by many observers and historians including Abubakar Aceh, A Hasyimi, Agus Sunyoto, Azmi Jamil, also Fatimi, Kern, and so on. (For details, please see Zulkifli's dissertation at Leiden University, entitled "The Struggle of the Shi'is in Indonesia, 2009).

Even Abdurahman Wakhid once stated that NU was culturally Syi'ah. This is because the Syafi'i tradition in Indonesia is different from Shafi'i in other countries - it is very much colored by Shia traditions. There are a number of typical Shia prayers which until now still run in Islamic boarding schools. There are certain wirid which clearly mention the five descendants of Ahlul Bait. Then also the tradition of the pilgrimage of the grave, then made a dome at the cemetery. According to him, it is all a Shia tradition. This tradition was born here in the form of Shafi'i schools. So, outside Shafi'i, in it Shia.

In Indonesia, in particular, the Shia have existed since the beginning of the entry of Islam into this earth khatulistiwa. Historian Slamet Muljana, for example, argues that Islam which was first spread in Southeast Asia was Shia Islam, and not Sunni. (See "Presenting the History of Shi'ah in the Archipelago", Dewa Gilang, Kompasiana).

This opinion of Slamet Muljana received support from A. Hasjmi. In his book "Syi'ah and Ahlu Sunnah", A. Hasjmi firmly stated that Shiite Islam was the first to arrive in Indonesia. Even the first Islamic empire in Indonesia, namely the Kingdom of Peurlak, was a Shiainspired, and not Sunni, kingdom.

The Executive Board of the Nahdlatul Ulama (PBNU) considers that the flow of Syi'ah Islam in general is not a cult. "It is not misguided, it is only different from us," said PBNU Chairperson, Said Aqil Siradj, at the presidential office, Jakarta, Tuesday, August 28, 2012. He said Shia was one of the Islamic sects that had existed since 14 centuries ago. This sect also exists in various parts of the world, including Indonesia. "The center is indeed in Iran," said. 
In his official meetings KH. Aqil Siradj often quoted the statement of his predecessor AlMarhum Abdurrahman Wahid (Gus Dur): "NU (Nahdhatul Ulama is Syi'ah minus Imamah, and Syi'ah is NU plus Imamah." Too many similarities between NU and Syi'ah.

Even the role and position of the kiyai in the NU tradition is very similar to the role and position of the Imam in the Shia tradition. Only, in NU the concept is present in the form of culture, while in Shia in the form of theology. This is the substance of Gus Dur's statement above, (From http://m.nu.or.id Saturday, 06/08/2011 18:33) PBNU general chairman Said Aqil Siroj stated, between NU and Shi'ites, many have in common in tradition, which is both respect for ahlul bait, or the descendants of the Prophet.

Even though in Indonesia, in particular, the Shia have existed since the beginning of the entry of Islam into this earth khatalustiwa. Even historian Slamet Muljana, argues that Islam which was first spread in Southeast Asia was Shia Islam, and not Sunni. (See "Presenting Shia History in the Archipelago", Dewa Gilang, Kompasiana). This opinion of Slamet Muljana received support from A. Hasjmi. In his book "Syi'ah and Ahlu Sunnah", A. Hasjmi firmly stated that Shiite Islam was the first to arrive in Indonesia. Even the first Islamic empire in Indonesia, namely the Kingdom of Peurlak, was a devout Muslim Shiite kingdom, and not a Sunnah.

Ironically, in Islamic boarding schools the books written by the Shiite schools of scholars are studied and studied in depth. "Nailul Awthor", for example, was composed by Ash-Syaukani who was suspected of being a Shiite Muslim. Even though the students were studying at the pesantren affiliated to NU. A case that proves that the Syi'ah have indeed existed since long ago in Indonesia.

Strongly believed today, the works of the great Syi'ah clerics are warmly welcomed by the majority of Indonesian scholars. The interpretation of "Al-Mizan", for example, is often a reference for Quraish Shihab in writing his phenomenal interpretation, "Al-Misbah". Similarly, the works of Murthado Muthahari and Ali Shariati greatly influenced the mindset of progressive Muslims in the country. It is said that the former Ketum of Muhammadiyah was very fond of the works of Ali Shariati.

As for the larger context, the Shia contribution to the world is very clear. Al-Azhar University, for example, is a legacy of the Fathimiyya Dynasty, which is of Syi'ah style. AlAzhar is currently recognized as the oldest and leading Islamic university in the world. Beyond that, there are many major Islamic thinkers who are believed to be Syi'ah religious 
followers. Names like Al-Farabi (philosopher), Ibn Sina (medicine), Al-Khawarizmi (astronomer), Jabir bin Hayyan (inventor of algebra), and At-Thusi (initiator of the observatory) are examples of so many names helped change world civilization. (Tim Kajian IKMAL, 2015: 17 -76)

These things show us that Syi'ah was not a school yesterday afternoon. And maybe because of this too, the MUI and the central NU have never issued a fatwa against the Syi'ah. So that it seems strange and awkward if lately there are a handful of individuals and groups who out of nowhere suddenly shout out loudly provoking Indonesian people with the heretical issue of Syi'ah. Allegedly they lacked reading the facts of history, presumably they were accustomed to being confined in the darkness of ignorance.

Based on historical data above, it can be concluded that Islam in Indonesia at the beginning of its entry only focused on two features, namely Shi'ite Islam and Sunnah Islam. Of the two groups, there are many opinions that say Syiah Islam is earlier than the Sunnah Islam. Even at the beginning of Islam there were tombstones and kingdoms, this confirmed that at that time Shia Islam was more dominantly developing in Indonesia.

From the above quotations, it is clear that there are many opinions that suggest the toleerance between syi'ah and sunnah, among others: 1. Gus Dur said that NU was a Shi'ah culturally, the proof of which was the tradition of the Shi'ah which was carried out by the Sunnah. He added: "NU (Nahdhatul Ulama is Shia minus Imamah, and Syi'ah is NU plus Imamah." Then said Alie Yafie (Indonesian Ulama): "Iran is a Syi'ah as an Islamic state in the OIC, meaning the Shiite is recognized as part of Islam, the entire Islamic world, which is incorporated in 60 countries accepts Iran as an Islamic state, and as a result the Shiite and Sunnah are Islam.

Furthermore, the opinions that contradict say; Shiite ideology has undermined many Islamic campuses in the world, so that the graduates who currently hold the leadership (Islamic Organizations). They had a chance to study this splinter religion completely. Even though they have to be willing to get the WAHABI stamp from them, the important thing is that the awareness of the danger of the Shia remains.

Finally, as researchers, it is certainly obligatory to achieve the main goal of finding tolerance between the two rival groups. There are so many arguments expressed by the two groups, it is clear that the two groups mentioned above cannot be integrated even though the world is doomed, therefore the only way is "tolerance", because both of them take refuge under one umbrella, namely Islam, both opinions above can not be put together so finally maintain differences, stay away from division, realize unity, with "tolerance". 


\section{History of the emergence of the Sunnah}

This flow emerged when the flow of mu'tazilah lost the influence and sympathy of the people, the figure of al-Asy'ari appeared with his own system of teachings, which was immediately accepted by the Muslim majority. The new kalam system is named the Asy'ariah stream, attributed to the name of the founder. His full name is Abu Hasan Ali ibn Ismail alAsh'ary, born in Basrah and died in Baghdad. He is a descendant of a friend of Prophet Musa al-Ash'ary. His name is abbreviated to Abu Hasan al-Ash'ary.( Abu Hasan al-Asy'ari, 1981: 7)

As a child, he studied with the famous Mu'tazilah teacher, al-Jubba'i. Al-Jubba'i himself was his stepfather who married Asy'ary's mother after his biological father died. (Abu Hasan Ali alHasani, 1968: 148). This flow he followed until he was 40 years old. When he reached the age of 40 he hid in his house for 15 days and then went to the Basrah mosque and said that he left the teachings and refused to understand mu'tazilah and his teachings. (Ahmad Hanafi, 1974: 58)

There are several theories about the background or reasons for the release of al-asy'ari from Mu'tazilah which he adopted for decades. According to the sources of al-Subki and Ibn ak Asakir, al-Asy'ari claimed that one night he dreamed that the Prophet Muhammad came to him while ordering him to abandon the Mu'tazilah understanding. Another source also said that al-Asy'ari argued with his teacher Abu Ali al-Jubba'i about the concept of al-Salah wa alAshlah, in relation to the fate of an adult believer, an infidel adult, and a young child in the hereafter. In the debate, the teacher cannot give a satisfactory answer to the student's question.

There are several theories about the background or reasons for the release of al-asy'ari from Mu'tazilah which he adopted for decades. According to the sources of al-Subki and Ibn ak Asakir, al-Asy'ari claimed that one night he dreamed that the Prophet Muhammad came to him while ordering him to abandon the Mu'tazilah understanding. Another source also said that al-Asy'ari argued with his teacher Abu Ali al-Jubba'i about the concept of al-Salah wa alAshlah, in relation to the fate of an adult believer, an infidel adult, and a young child in the hereafter. In the debate, the teacher cannot give a satisfactory answer to the student's question.

Apart from the two theories already mentioned, there is an analysis which states that in al-Ash'ari there has indeed arisen doubts about the teachings of the Mu'tazilites that he has embraced so far, according to his history he lived alone for 15 days to reflect on the teachings intended. After spending 15 days of contemplation he went out of the house to go to the mosque and climbed the pulpit as he delivered his speech before the audience as follows: Ladies and gentlemen, all this time I have isolated myself to reflect on the statements and 
arguments put forward by each group. These arguments in my thinking are just as strong. Therefore, I asked for guidance from God. By his instructions, I now leave the old ideas and adheres to the new understanding that I wrote in these books. I abandoned the old ideas as I took off this shirt.

Regardless of whether or not some theories have been put forward, it is clear that alasy'ari left Mu'tazilah when this group was in a phase of decline and weakness. It was in this atmosphere of decline that al-Asy'ari built a new kalam system in accordance with the understanding of those who clung to the Sunnah. Whatever the causes and motives for the release of al-Asy'ari from Mu'tazilah, which is clear, he is very instrumental in giving a system of thought which can be accepted by the majority of Muslims. More than that, al-Ash'ari has contributed to making the science of kalam become lawful and widely accepted in the Islamic world, which was previously highly suspected of even being seen as heresy and heresy and forbidden, which is then known as the Ahl al-school Sunnah wa al-jama'ah. (Suryan A. Jamrah, 2007: 131)

Ash'ary as a person who has struggled with Mu'tazilah thinking cannot be separated from the use of reason in arguing thoughts. Therefore he strongly opposed those who objected to defending religion with the argumentation of mind as in his book Ihtihsan alKhawadh fi-Ilm al-Kalam. (Ahmad Hanafi, 1974: 58). In many ways he tried to find a middle ground between many schools in the past, especially between the rationalist and textualist groups.

Since its birth, the al-Asy'ari sect was immediately accepted and adopted by the majority of the people. This flow has survived until now and has succeeded in dominating most, if not all, of the Islamic world, especially in areas where Syafi'iyah jurisprudents live. As is customary in the history of schools and schools, during the period of its occupation, Ash'ariyah was still at the stage of formation, and its development was only seen after being left alone.

Similarly, in terms of methodological aspects, al-Asy'ari came up with the "middle way" method which certainly had a greater chance to be widely accepted by the public as a group, both middle and upper middle class. More than that, the history of thought has proven that the method of the "middle way" always lasts long because it is more acceptable from the past. Conversely, any extreme thinking will never survive and it is difficult to get a majority of followers. Previously, the dynamics of the jurisprudence school had proven, how the Shafi'i school always survived and was accepted by he majority of Muslims in the world, because, 
al-Syafi'i adopted the "middle way" method between Hanafi schools which prioritized aspects of aqli and hanafi schools which emphasized the naqli side .

\section{Syi'ah closeness with the Sunnah}

Culturally the closeness between the Sunni-Syi'ah in the traditions and religious rituals of Indonesian Muslims can no longer be denied. The fact that the tradition of tahlilan, khaul, diba'an, and praying for deceased spirits practiced by the majority of Muslims in Indonesia bears a resemblance to the practice of Shiites. Likewise in the tradition of maulid reading in every Friday night, besides having similarities in the reading in the book, the names of priests who were recognized by the Shiites were also included.

In the tarekat tradition. the two most dominant tarekat in Indonesia, Qadiriyah and Naqshabandiyah, have links (sanad) to Imam Ali Musa al-Rida (seventh priest), Imam Musa al-Qasimi (sixth priest), Imam Ja'far al-Sadiq (fifth imam) , Imam Muhammad al-Baqir (fourth priest), Imam Ali Zainal Abidin (third priest), Imam Husein (second priest), and Imam Ali bin Abi Talib (first priest). That means, spiritual figures recognized by the Sunnis are also recognized by the Shiites.

Even among Syi'ah, Ayatollah Khomeini is also known as a commentator on the book ihya 'Ulumuddin by al-Ghazali which is the main reference for the Ahlus-Sunnah. Ali Khemenei, the son of Khomeini who has become the highest Syi'ah spiritual leader in Iran today, has also translated into Persian Tafsir fi Dzhilalil Quran by Egyptian Sunni cleric Sayyid Qutb. In fact, the main hadith books of the Ahlus-Sunnah followers, such as those of Bukhari and Muslim, were also studied in Shia educational institutions.

Until this moment, a number of Syi'ah institutions continued to grow in the midst of Muslims who were predominantly Ahlus-Sunnah followers. Like the Mutahhari Foundation in Bandung, West Java, the Al-Hadi Islamic Boarding School in Pekalongan, Central Java, the Islamic Boarding School Foundation (YAPI) in Bangil, East Java, Al-Ishlah in Ujung Pandang, South Sulawesi. ICC (Islamic Cultural Center), an Islamic Shiite study institute in the capital. The first Shi'ite Islamic tradition entered Indonesia, among others, through the path of Sufism several hundred years ago, but the 1979 Islamic Revolution in Iran grew Shiites into an ideology that attracted intellectuals.

Indonesian ABI Sharia Council member Muhsin Labib said, citing a study, one proof that Syi'ah influence had developed in Indonesia for a long time, can be seen from the similarity of several Syiah traditions with Sufism practices, Kejawen teachings and the values taught by the Wali Songo on Java. "The teachings of pantheism, such as the free kawulo union, 
are in sync with the theological views of Syi'ah," Muhsin Labib told BBC Indonesia reporter Heyder Affan, by telephone, Thursday (09/13). That is just one example, Muhsin said, how long the Syi'ah teachings have been absorbed in Indonesian society. "Then we see traces and historical sites that confirm the presence of the Shiites in Indonesia, long before Arab Islam appeared on the archipelago." Member of the Indonesian Ahlulbait Shura Council, Muhsin Labib. "Then we see traces and historical sites that affirm the presence of the S yi'ah in Indonesia, long before Arab Islam emerged on the archipelago," said Muhsin, "for example in Aceh, Bengkulu, Solo palace, there is (tradition) Suro ..." Therefore, continued Muhsin, many terms in Indonesian originating from Persia. "For example the skipper, the airport, Shah ... It all connects there is a fairly long relationship between Shia and Indonesia. And," people wearing black caps can be associated with the symbol of Syi'ah, "said Doctor Muhsin Labib, who is also a staff member lecturer at Paramadina University, Jakarta.

Other evidence, according to the post-graduate teaching staff at the Syarif Hidayatullah State Islamic University, Jakarta, Doctor Fuad Jabali, can be traced from manuscripts and books written in the 16th and 17th centuries in the archipelago. It is believed that there is a closeness to the Syi'ah and Nahdlatul Ulama traditions in Indonesia. The books written by the ulama, according to him, show the strength of Syi'ah influence in the archipelago. "If you read it, you can easily see how powerful Persian or Syi'ah influence is," he told BBC Indonesia. From this historical reality, he continued, shows how the Shia tradition is able to be accepted by local communities in the archipelago. "There is no problem right ..." On his journey, the second wave of Shiite influence to Indonesia was marked "the presence of certain figures associated with taraqih alawiyin (from Hadramaut, Yemen)", said Muhsin Labib.

"From this historical reality, he continued, shows how the Syi'ah tradition is able to be accepted by local people in the archipelago." Doctor Fuad, teaching staff at UIN Syarif Hidayatullah, Jakarta. "It strengthens the Syi'ah community with the Nahdlatul Ulama (NU) family. So the habib can be an important position in the NU community," he said. Although the entry of Islam into Indonesia is believed by some experts to contain elements of Syi'ah, there is no agreement among historians. Observers of the Islamic issue of Azyumardi Azra, for example, stated "the entry and development of the Syi'ah in Indonesia from a historical perspective is still controversial". He said in a preface titled Syi'ah in Indonesia: between myth and reality, in the Shia and Political books in Indonesia, a study by A Rahman Zainuddin and M Hamdan Basyar (published by Mizan, 2000). 
Apart from the polemic about the truth of history, a number of people recorded the events of the Iranian Islamic Revolution in 1979 as the next wave of Shiite influence into Indonesia. The Iranian Islamic Revolution in 1979 was inspired by a highly respected Syi'ah figure, Ayatollah Khomeini.

"The second wave was marked by an intellectual nature," said Jalaludin Rahmat, in Kang Jalal's Note book, Vision Media, Politics and Education (1998). In these times, according to Jalaludin who is also the Chair of the Shura Council of the Ahlulbait Indonesian Congregation, the sympathetic people of this Shia "mostly come from universities". Most of them, he continued, were also interested in Shia as "an alternative to existing Islamic thoughts" "They are more interested in Syi'ah thought than in their rites or jurisprudence," he explained. "In terms of ideology, they tend to be radical".

In the view of Doctor Fuad Jabali, Iran's Islamic Revolution became an attraction for some educated Muslims, because "it provides answers to a big problem that cannot be answered by the Sunni community and tradition". "They are more interested in Syi'ah thought than in their rites or jurisprudence," he explained. "In terms of ideology, they tend to be radical," Jalaludin Rahmat, Chairperson of the Shura Council of the Indonesian Al-Ahlulat Congregation. He then gave an example: "For example, in the world of Sunni Muslims, because political and religious authority is left to the majority of people, there will be wider conflicts, because each of them claims to be better than others ... There is no mechanism or method to choose an acceptable leadership."

Such problems, according to him, do not exist in Syi'ah Islam. "Syi'ah is very solid because of the concept of Imamah, because leadership is left to one person." In this period, according to Jalaludin Rahmat (in an interview with the Republika daily, Thursday, August 30, 2012), the spread of Syi'ah has not been a threat. "Because, it is only considered an intellectual movement. They do not discuss fiqh". "So the second wave did not cause riots," he said.

However, according to Jalaludin Rahmat in his book (1998), there was a change in approach when the next wave appeared "which was marked by the presence of Qum alumni who were more oriented towards the fiqh approach". "When they came to Indonesia, they fulfilled the need for this jurisprudence," he wrote.

"They started giving Syi'ah recitations in various places". In an interview with Republika, Jalaludin Rahmat said, in the 1990s the habib who returned from Qum, Iran, "began to teach the Shia to a limited circle. Like Ustad Umar in Palembang and Ustadh Husein Al Habsyi in East Java. They came with Syi'ah fiqih" . In its development, "the seeds of conflict began ... Because at the stage of thinking, there was no friction," Jalaludin said. So far, said Jalaludin, many Syi'ah communities inhabit Jakarta, Bandung, Sampang, Makassar and others. 


\section{Meeting Point Syi'ah - Sunniy A Solution}

Although there are differences in understanding between Syi'ah-sunni, but the closeness is very clearly seen in the syi'iy culture that is used by Sunniy, as above. However, Syi'ah in Indonesia is different from Iran and Iraq. One of them is Prof. Dr. Nur Syam, Chancellor of IAIN Sunan Ampel Surabaya, in the SURYA daily on Saturday (12/31/2011) said that Syi'ah in Indonesia had been 'Indonesian'. Adapting to Indonesian culture.

In this context, it is interesting if we read the results of Prof.'s dissertation research. Dr. Mohammad Baharun, M.Ag, a lecturer at IAIN Surabaya about the character of Syi'ah Indonesia. According to him Syi'ah in Indonesia is not monolithic. Even so, Prof.'s research Baharun concluded for many years that they were united by one essential doctrine, namely the doctrine of Imamah.

Apparently, the factor of Syi'ah's character differences in Indonesia was not because of culture, Indonesian culture. However, the level of understanding of the Shi'ah adherents to the doctrine of the Imamate gave birth to a different typology. The Indonesian cultural and cultural factors only color the skin, not to change the view of faith, or its main doctrines. In conclusion, Syi'ah in Indonesia basically according to Prof. Baharun is the same as Syi'ah in Iran, namely Syi'ah Istna 'Istna Asy'ariyah. Moreover, the spread was carried out by Indonesian alumni of the Qom Iran University.

The most central aqeed and absolute nature in Syi'ah Itsna Asy'ariyah is the Imamate faith. Believing in the twelve Imams he called ma'shum (free of errors), as ma'shum the Prophets. In the sense of Syi'ah, Imammah is not like Imamah in the Ahlus Sunnah concept of wal Jama'ah. But Imamat is the primary doctrine in ideology and theology.

In understanding Ahlus Sunnah Imamah also called the Caliph, the ruler and supreme leader of the people after the Prophet SAW. The word imam is also referred to in the Qur'an in various forms, besides meaning the leader is also another meaning, for example, which is called in QS. Al-Ahqaf Imam means the Qur'an. Said the priest also means the leader of the army and regulator of benefit (QS. Al-Baqarah: 24). The Imam in the sense here is not a substitute leader of the Prophet SAW. Only.

In the hadith of the Prophet, found the terms imamat, khilafah, and imarah which all mean leaders. Both prayer leaders, or state leaders. like the hadith of the Prophet SAW who told Abu Bakr to lead the prayer when the Prophet was sick. "From Abdullah he said: When the Prophet Muhammad died, the Ansar said:" It is better for us to be chosen by a leader and from you a leader. "Umar asked:" Do you not know that the Messenger of Allah chose Abu Bakr to be an imam in prayer? "Therefore if one of you more afdhal than Abu Bakr, then 
leave (leave) Abu Bakr. They replied: "We took refuge from Allah to turn our backs on Abu Bakr".

For Syi'ah Imamiyah, understanding the traditions of the Imamat doctrine must not only come from the Prophet Muhammad, but also from the twelve priests as holy men (ma'shum). The absoluteness of the priest as a leader who is free from sin has implications for the concept of hadith. The sayings of the priests are called hadith. As written in al-Kafi Volume I page 52 of hadith no. 14: "Abu Abdillah as (Imam Ja'far al-Sadiq) said, that my hadith is the hadith of my father (Imam Muhammad al-Baqir), my father's hadith is the hadith of my grandfather (Imam Ali Zainal Abidin), my grandfather's hadith is al-Hussein's hadith (third priest), the hadith of al-Hussein is the hadith of al-Hasan (2nd priest) and the hadith of alHasan is the Hadith of Amir al-Mu'minin (first Imam), and the hadith of Amir al-Mu'minin is the hadith of the Prophet SAW is the hadith of the Prophet Muhammad is the word of Allah SWT ".

The categorization and measurement parameters of the hadith are called shahih or not different from the hadith in the Ahlus Sunnah concept of wal Jama'ah. According to Syi'ah, hadith is called saheeh with conditions; First, because the hadith is narrated from a trusted source. Second, because the hadith is in line with other definite arguments (qat'i) and in line with the trusted context. From this understanding (the Prophet's hadith is identical to the hadith of the Imams), the doctrine of Imamat in Syi'ah Itsna 'Asyariyah is a necessity. Even when Twelve Syiah was present, it must have practiced this essential doctrine.

There are some experts trying to survey / confirm this doctrine to a number of Syi'ah people and educational institutions in East Java. They honestly believe that the words of the Imam are called hadiths, and they cannot be wrong. The word priest is a definite law. In their view, the Imamat is the successor to the Nubuwwah who is appointed based on Divine texts, because the sayings of the Imams are identical to the hadith of the Prophet originating from the revelation of Allah SWT.

There are indeed followers of Shi'ah who openly teach in private to their own circles. The various responses of the Shi'ites were also influenced by the level of their understanding of the doctrine of the absolutes of Imamat. The model of appreciation of the aquality of the creed of the Imamate gave birth to a different model of behavior of followers of Syi'ah. In addition, Syi'ah's adaptation pattern among the Sunni majority also affected the behavior of followers of Syi'ah Imamiyah. Generally, Syi'ah is reluctant to be honest with other groups, except for fellow ikhwan Syi'ah. "Syi'ah and Sunnah are great blessings that we must be grateful for. The difference between the two Islamic schools is too little compared to the existing equation. 
Differences and diversity are reasonableness, while disputes and quarrels are bad, "said Iranian President Hasan Rouhani in a speech delivered during a visit to Sistan-Baluchestan province in 2014.

Like other places in Indonesia, Sunni Muslims are the majority citizens in Jepara. Most of them are also members of the country's largest Muslim organization, Nahdlatul Ulama (NU). But in Banjaran there is also the Darut Taqrib Islamic Boarding School, which embraces Shiite Islam. About 200 Shia families live in the area, they feel safe carrying out their beliefs.

According to Miqdad Turkan, the leader of the Darut Taqrib Islamic Boarding School, various factors made Sunnis and Shiites live in harmony. In fact, not infrequently they are shoulder to shoulder in social activities such as blood donor activities and raising aid for humanitarian disasters.

As a Port City that has been touched by various religious influences including Christianity, Hinduism, Buddhism and of course Islam, Jepara recognizes diversity as a distinctive feature of their region, this phenomenon is a portrait of "tradition" of diversity in a port city that is still in many other regions in Indonesia.

There is no historical root in the Sunnah - Syi'ah dispute in Indonesia. Ibn Bathutah, a Moroccan sailor once traveled to the Pasai Ocean in the 13th century ago. In his diary, he recorded that the Persian influence (which was the center of Shiite civilization) was so much found in the Kingdom of Pasai. The Deputy Admiral of the Kingdom of Pasai was called the Persian Behruz. In fact, the use of absorbed vocabulary from Persian to Malay seems popular in Pasai. Kanduri (festivity), astana (palace), city (port), diwan (council), trophy, word, and so on.

The commemoration of Hussein's death in Karbala which fell on Muharram 10 every year is also commemorated in several regions in the archipelago. In Aceh Muharram was called "Asan-Usen", in West Sumatra "tabuik month", and in Java "sura month". Not to mention the naming of the kings in various parts of the archipelago who used the titles of Sayyid and Sharif, such as Sayyid Jamaluddin Agung who became king of Palembang or Syarif Hidayatullah in Cirebon, a title tethered to the descendants of the Prophet in the Syi'ah tradition. 


\section{CONCLUSION}

Based on the results of this study, it can be concluded that there are several methods of tolerance between Syi'ah-sunni which must be applied, including:

1. In terms of the name Syi'ah is a group of Muslims who claim that saidina Ali ra. is the person who has the right to be the successor caliph, because the Prophet SAW. testified that his successor after death was saidina Ali bin Abi Talib.

2. In terms of history, they both believe there is a substitute for the Prophet. that is in the syi'ah group, saidina Ali ra. minus three caliphs, while the sunnah group saidina Ali ra. plus three other caliphs. According to Syi'ah Ali's appointment was based on revelation, while the appointment of the Caliph according to the Sunnah through a friend's ijtihad. Such understanding does not damage the joints of faith in Islam, because they both hold to the Qur'an and the Sunnah.

3. In terms of culture the Sunnah is culturally Shiite. The proof is that there is a typical Shia tradition that is still carried out by the Sunnah; such as: the tradition of the pilgrimage of the grave, tahlilan, the ark and so on. This tradition was born in the form of Shafi'i schools. So, outside of Shafi'i, in it Syi'ah, or vice versa the tradition of Shi'a in it is Sunnah.

4. In terms of teaching, one of the syi'i sects closest to Sunniy is: Zaidiyah recognized the validity of the Caliph or Imamat of Abu Bakr As-Sidiq and Umar bin Khattab and Uthman ibn Affan. But the Caliph of Sayidina Ali bin Abi Talib was judged to be higher than the three Caliphs above. This is the Shiite sect that is closest to the Sunnah.

5. The point of difference between syi'ah and the sunnah, lies only in the will of the prophet at Ghadir Khumm, then develops on others, all of them do with strong arguments, while the sunnah is denied.

6. The difference in understanding between syi'ah and the sunnah, according to them, triggers conflict and mutual infidelity, will not be able to be integrated even though the world of doomsday. If they (Sunnah) forgive Syi'ah, obviously the opposite will happen, because that is the only way that must be taken is mutual tolerance.

7. The rationale for the Shi'ites to practice it is because of the reason they hold strong arguments, but the Sunnah accuse their arguments of being weak. The accusation is reasonable, because the glasses they use are different. 
8. The view of the Syi'ah towards his understanding is the same as that of the Sunnah expert on his understanding. Will not be able to afford any persuasion, policy, coercion, humiliation or even expulsion or murder that changed him. Because that is the conclusion, amamah according to each other's understanding, maintain differences and stay away from division, turn on tolerance. 


\section{BIBLIOGRAPHY}

Abu Zahrah, Muhammad, 1996. Aliran Politik Dan Aqidah Dalam Islam, Jakarta : Logos Publishing House.

Ahmad Syafii Maarif dkk, Maarif, 2015. Arus Pemikiran Islam dan Sosial, Syi'ah Sekterianisme dan Geopolitik, Jakarta: Jurnal, Vol. 10, No. 2-Desember.

A. Nasir, Sahilun, 2010. Pemikiran Kalam (Teologi Islam) Sejarah, Ajaran, dan Perkembangannya, Jakarta: Raja Grafindo Persada.

Ali. M Suyuti, 2000. Metode Penelitian Agama, Jakarta: Raja Grafindo.

al-Asy'ari, Abu Hasan, 1981. al-Ibanah 'an Ushul al-Diyanah. Damascus-Beirut: Maktabah DarBayan. al-Hasani, Abu Hasan Ali, 1968. Rijal al-Fikr wa al-Da'wah fi al-Islam. Damascus: Maktabah Dar-Bayan.

Al-Khotib, Sayyid Muhibudin, 1984. Mengenal Pokok-pokok Ajaran Syi'ah Al-Imamiyah, Surabaya: PT.bina ilmu.

A. Jamrah, Suryan. 2007. Studi Ilmu Kalam. Pekanbaru: LSFK2P.

Bakkers, J. SJ. 1979. Agama dan Alam Kepercayaan Asli di Indonesia, Jakarta: Cipta Loka Caraka.

Baidhawy, Zakiyuddin \& Mutohharun Jinan (eds.), 2003. Agama dan Pluralitas Budaya Lokal, Surakarta : PSB-PS UMS.

Bogdan, R. \& S.J. Tylor, 1993. Kualitatif Dasar-Dasar Penelitian (terjemahan), Surabaya: Usaha Nasional.

Budi, Trisakti, 2016. 4 Hak Rasulullah yanh terabaikan, Upaya Mengenang JasaJasa Nabi Saw. dan Implementasi Balas Budi Umat. Marja, Bandung.

Funk and Wagnalls, 1984. Standars Desk Dictionary, Cambridge : Harper and Row.

Jalaluddin Rakhmat, 2015. Misteri Wasiat Nabi, Asal Usul Sunnah Sahabat : Studi Historiografis Atas Tarikh Tasyri', Bandung: Misykat.

Lerner, Daniel. 1978. Memudarnya Masyarakat Tradisional (Terj.). Yogyakarta: Gadjah Mada University Press.

------, 1999. Metoda Penelitian Pendekatan Kualitatif, Bandung : Primaco Akademika.

Marzuki, 1989. Metodologi Riset, Jakarta: Fakultas Ekonomi. Universitas Indonesia.

Moleong, Lexy J., 2000. Metode Penelitian Kualitatif, Bandung : Remaja Rosdakarya

Muhaimin, AG., 2001. Islam dalam Bingkai Budaya Lokal Potret dari Cirebon, Jakarta Logos.

Musthafa Muhammad, 2008. Islam Tanpa Mazhab, Terj. Abu Zaidan Al-Yamani \& Abu Zahrah Al-Jawi Solo: Tiga Serangkai.

Maarif, Ahmad Syafii, dkk. 2003. Syiah, Sekretarianisme dan Geopolitik, Jakarta: Jurnal, No. 2 Desember. 
Nasution, Harun, 1986. Teologi Islam: Aliran-aliran Sejarah Analisa Perbandingan, Jakarta: UI-Press.

Nasution, S., 1996. Metode Penelitian Naturalistik Kualitatif, Bandung: Tarsito.

Ozbay, Ferhunde (ed.). 1988. Women, Family, and Social Change in Turkey. Bangkok: 1990.0zbudun, Ergun (ed.). Perspectives on Democrasy in Turkey. Ankara: Sevinç Matbaasi.

Redfiled, Robert, 1961. The Little Community and Peasant Society and Culture, Chicago: Chicago University Press.

Razak, Abdur dan Anwar, Rosihan, 2006. Ilmu Kalam, Bandung: Puskata Setia.

Soehartono, Irawan, 1995. Metode Penelitian Sosial, Bandung: Rosadakarya.

Sayyid Muhibudin, Al-Khotib, 1984. Mengenal Pokok-pokok Ajaran Syi'ah Al-Imamiyah, Surabaya:PT.bina ilmu.

Syahrastani, Muhammad bin Abd Al-Karim, 1951. Al-Milal wa An-Nihal, Beirut-Libanon: Dar al-Kutub al-'Ilmiyah.

Sinanoglu, Suat. 1989. Aspects of Turkey. Ankara: Demircioglu Matbaacilik.

Sirriyeh, Elizabeth. 1999. Sufis and Anti-Sufis. England: Curzon Press.

Sonyel, Salahi R. 1989. Ataturk-The Founder of Modern Turkey. Ankara: Turkish Historical Society Printing House.

Tim Kajian IKMAL, 2015. Syi'ah antara Fitnah dan Fakta, TT, Titisan.

Turner, Bryan S. 1984. Sosiologi Islam: Suatu Telaah Analitis atas Tesa Sosiologi Weber (terj.). Jakarta: Rajawali Pers.

1981. Atatürk's Republic of Culture. New York: The Office of the Ambassador for Cultural Affairs, Republic of Turkey.

2000. The Ottomans A Brief Story of World Empire. Ankara: Ministry of Foreign Affairs of the Republic of Turkey.

--------2001. Turkey and the European Union: an Overview. Ankara: The Ministry of Foreign Affairs of the Republic of Turkey.

Usman, Husaini dan Purnomo Setiady Akbar, 1996. Metodologi Penelitian Sosial, Jakarta: Bumi Aksara 